\title{
Genetic Divergence Studies in Rice (Oryza sativa L.) Hyrids for Yield, Yield Component Traits and Quality Parameters
}

\author{
M. Devi ${ }^{1}{ }^{*}$, D.P.B. Jyothula ${ }^{1}$, B. Krishnaveni ${ }^{1}$ and V.S. Rao ${ }^{2}$ \\ ${ }^{1}$ Department of Genetics and Plant breeding, India \\ ${ }^{2}$ Department of Statistics and Computer applications, India \\ *Corresponding author
}

\section{A B S T R A C T}

\section{Keywords}

Rice hybrids, Genotypes, Clusters and $\mathrm{D}^{2}$ analysis

Article Info

Accepted:

15 May 2019

Available Online:

10 June 2019
Genetic divergence was assessed among 20 rice hybrids with 15 characters from different eco-geographical regions of India using Mahalanobis' $\mathrm{D}^{2}$ analysis. The experimental materials were evaluated during kharif- 2017 at Agricultural College Farm, Bapatla, Andhra Pradesh, India. The 20 rice hybrids were grouped into 5 clusters. Out of five clusters, maximum number 9 of genotypes are in cluster I. Cluster II is second largest with 6 genotypes followed by cluster IV with 3 genotypes. Clusters III and V possess one genotype each. The pattern of distribution of genotypes from different eco-geographical regions into various clusters was at random indicating that geographical diversity and genetic diversity were not related. Based on the perse performance and cluster mean values of characters, it can be concluded that, the hybrid S-8001 which is present in the cluster II is found to be superior over other hybrids and checks in the present study by having high mean values for the economically important characters viz., number of total grains per panicle, number of productive tillers per plant and grain yield per plant.

\section{Introduction}

The slogan 'Rice is life' aptly describes the importance of rice in food and nutritional security. Rice (Oryza sativa L.) is the world's second most important cereal crop and staple food for more than $60 \%$ of the global population providing about $75 \%$ of the calorie and $55 \%$ of the protein intake in their average daily diet. In India, rice is grown in $44.0 \mathrm{mha}$ with the production of $108.50 \mathrm{mt}$ and productivity of 2.4 t/ha. during 2016-17 (Directorate of Economics \& Statistics, 201617). Maintaining stable rice production is extremely important to feed the constantly growing population. For the estimated population of 1.63 billion people by the year 2050 with a per capita rice consumption of 225 to $275 \mathrm{~g}$ /day, country would require 133 to $162 \mathrm{M} \mathrm{t}$ of rice (Directorate of Rice Research, 2013). In the present scenario the rice productivity has reached a plateau.

In order to achieve the expected targets, we have to develop the varieties with higher yield potential by breaking the existing yield plateau through utilizing more diversified parents in breeding programmes. 
The success of any plant breeding programme largely depends on the existence of diversity among the genotypes (Allard, 1960). This helps in the choice of parents for hybridization in yield improvement programmes. Hence, estimation of genetic diversity for yield and its components among genotypes is important for planning the future hybridization programme. The use of Mahalanobis' $\mathrm{D}^{2}$ statistics for estimating genetic divergence has been emphasized by Sarawgi and Bisne (2007). Hence, the present investigation was carried out in the southern block of Agricultural College Farm, Bapatla to ascertain the value and magnitude of genetic diversity of 20 rice genotypes and to select suitable genotypes.

\section{Materials and Methods}

The present investigation was carried out during kharif, 2017 at Agricultural College Farm, Bapatla. The experimental material consisted of twenty genotypes (15 Hybrids + 5 Checks) of Rice (Oryza sativa L.) obtained from Indian Institute of Rice Research (IIRR), Rajendranagar, Hyderabad, Telangana, which were sown in nursery beds and transplanted into the main field in Randomized Block Design in three replications with a spacing of $15 \mathrm{x} 15 \mathrm{~cm}$.

Single plant observations were recorded on five plants selected at random per genotype per replication for characters viz., plant height $(\mathrm{cm})$, number of productive tillers per plant, panicle length $(\mathrm{cm})$, number of total grains per panicle, grain yield per plant (g) and their means were used for statistical analysis. However, observations on days to $50 \%$ flowering, days to maturity were recorded on plot basis and all grain quality parameters $v i z$, hulling percentage, milling percentage, head rice recovery percentage, L/B ratio, water uptake, kernel elongation ratio, volume expansion ratio and amylose content were done as per DRR laboratory manual on rice grain quality procedures. Genetic divergence analysis was done following the $\mathrm{D}^{2}$ statistics proposed by Mahalanobis (1936).

\section{Results and Discussion}

The analysis of variance showed significant differences among the genotypes for all the characters. The 20 genotypes were grouped into 5 clusters using the Tocher's method with the criterion that the intra cluster average $\mathrm{D}^{2}$ values should be less than the inter cluster $\mathrm{D}^{2}$ values. The distribution of 20 genotypes into 5 clusters is presented in Table 1. The distribution of 20 genotypes into 5 clusters was at random with maximum number of 9 genotypes in cluster I. Cluster II is the second largest with 6 genotypes followed by cluster IV with 3 genotypes. As could be seen from the results that cluster III and V were solitary clusters. The formation of distinct solitary clusters may be due to the fact that geographic barriers preventing gene flow or intensive natural and human selection for diverse and adoptable gene complexes must be responsible for this genetic diversity. These results were in accordance with Dutta et al., (2011), Vennila et al., (2011), Chakravorty and Ghosh (2012), Singh et al., (2012), Karuppaiyan et al., (2013), Manohara and Singh (2013), Allam et al., (2014), Bhadra and Roy (2014), Ramanjaneyulu et al., (2014), Beevi and Venkatesan (2015), Kumar et al., (2015), Bharathi et al., (2016), Chandramohan et al., (2016) and Ashok et al., (2017).

The maximum intra cluster $\mathrm{D}^{2}$ value was 95.18 for cluster IV followed by 90.27 for cluster II, 41.08 for cluster I, while it was zero for clusters III and V as shown in Table 2. The high intra cluster distance in cluster IV indicated the presence of wide genetic diversity among the genotypes viz., HRI-195, RTNRH-11 and NS-6816. Cluster mean 
values showed wide range among the genotypes studied, which indicates the presence of variation among the genotypes studied. The maximum inter cluster $\mathrm{D}^{2}$ values was observed between cluster II and $\mathrm{V}$ (444.87) followed by cluster I and V (267.50). Intra and inter cluster distance of 20 rice genotypes are showed in the Figure 1.

Table.1 Clustering pattern of 20 genotypes of rice (Oryza sativa L.) by Tocher's method

\begin{tabular}{|c|c|l|}
\hline $\begin{array}{c}\text { Cluster } \\
\text { No. }\end{array}$ & $\begin{array}{c}\text { No. of } \\
\text { genotypes }\end{array}$ & \multicolumn{1}{|c|}{ Name of the genotypes } \\
\hline I & 9 & $\begin{array}{l}\text { MEPH-143, 27P63 (NCH-2), BPT-5204(NCV-2), } \\
\text { CRHR-115, NK-23831, W+GL-14(NCV-1), US-308, } \\
\text { CRHR-116, CRHR-118 }\end{array}$ \\
\hline II & 6 & $\begin{array}{l}\text { PHI-17108, CRHR-119, JKRH-3333 (NCH-1), S-8001, } \\
\text { Indam-200-043, NPH-2899 }\end{array}$ \\
\hline III & 1 & RRX-135 \\
\hline IV & 3 & HRI-195, RTNRH-11, NS-6816 \\
\hline $\mathbf{V}$ & 1 & ADT-49 (ZCV) \\
\hline & & \\
\hline
\end{tabular}

Table.2 Average intra and inter cluster $\mathrm{D}^{2}$ values among five clusters in 20 rice (Oryza sativa $\mathrm{L}$.) genotypes

\begin{tabular}{|l|l|l|l|l|l|}
\hline Cluster No & \multicolumn{1}{|c|}{ Cluster I } & \multicolumn{1}{|c|}{ Cluster II } & Cluster III & Cluster IV & \multicolumn{1}{c|}{ Cluster V } \\
\hline Cluster I & $\mathbf{4 1 . 0 8}$ & 127.17 & 88.74 & 152.36 & 267.50 \\
\hline Cluster II & & $\mathbf{9 0 . 2 7}$ & 229.30 & 176.61 & 444.87 \\
\hline Cluster III & & & $\mathbf{0 . 0 0}$ & 227.43 & 168.70 \\
\hline Cluster IV & & & & $\mathbf{9 5 . 1 8}$ & 226.74 \\
\hline Cluster V & & & & & $\mathbf{0 . 0 0}$ \\
\hline
\end{tabular}

Diagonal bold values indicate intra cluster distances 
Table.3 Mean values of five clusters by Tocher's method for 20 genotypes of rice (Oryza sativa L.)

\begin{tabular}{|c|c|c|c|c|c|c|c|c|c|c|c|c|c|c|c|}
\hline $\begin{array}{c}\text { Character / } \\
\text { Cluster } \\
\text { number }\end{array}$ & $\begin{array}{c}\text { Days to } \\
50 \% \\
\text { Flowering }\end{array}$ & $\begin{array}{l}\text { Days to } \\
\text { Maturity }\end{array}$ & $\begin{array}{c}\text { Plant } \\
\text { Height } \\
\text { (cm) }\end{array}$ & $\begin{array}{c}\text { Number } \\
\text { of } \\
\text { producti } \\
\text { ve tillers/ } \\
\text { Plant }\end{array}$ & $\begin{array}{c}\text { Panicle } \\
\text { Length } \\
\text { (cm) }\end{array}$ & $\begin{array}{c}\begin{array}{c}\text { No. of } \\
\text { total } \\
\text { grains/ } \\
\text { Panicle }\end{array}\end{array}$ & Hulling \% & $\begin{array}{c}\text { Milling } \\
\%\end{array}$ & $\begin{array}{c}\text { Head } \\
\text { Rice } \\
\text { Recovery }\end{array}$ & $\begin{array}{c}\text { Volume } \\
\text { Expansio } \\
\text { n Ratio }\end{array}$ & $\begin{array}{l}\text { Water } \\
\text { Uptake }\end{array}$ & $\begin{array}{c}\text { L/B } \\
\text { Ratio }\end{array}$ & $\begin{array}{c}\text { Kernel } \\
\text { Elongation } \\
\text { Ratio }\end{array}$ & $\begin{array}{l}\text { Amylose } \\
\text { Content }\end{array}$ & $\begin{array}{c}\text { Grain } \\
\text { yield/ } \\
\text { plant (g) }\end{array}$ \\
\hline Cluster I & 98.55 & 127.88 & 131.65 & 18.00 & 24.37 & 311.07 & 83.07 & 72.22 & 59.66 & 3.625 & 112.03 & 2.97 & 1.78 & 23.40 & 46.85 \\
\hline Cluster II & 100.66 & 129.38 & 128.45 & 18.38 & 22.60 & 369.38 & 84.61 & 74.05 & 61.94 & 3.661 & 225.00 & 2.81 & 1.77 & 22.84 & 54.33 \\
\hline Cluster III & 102.00 & 130.00 & 114.60 & 15.33 & 23.36 & 244.66 & 87.33 & 77.00 & 73.66 & 3.707 & 103.33 & 2.53 & 1.87 & 24.60 & 28.66 \\
\hline Cluster IV & 88.00 & 117.00 & 136.02 & 19.22 & 23.64 & 350.33 & 82.55 & 72.11 & 56.33 & 3.703 & 198.88 & 2.78 & 1.68 & 22.77 & 41.00 \\
\hline Cluster V & 89.66 & 119.00 & 96.66 & 18.33 & 22.76 & 220.00 & 82.33 & 70.00 & 54.00 & 3.647 & 115.00 & 2.90 & 1.80 & 23.10 & 29.00 \\
\hline
\end{tabular}

Bold figures are indicated maximum and minimum mean values for each character. 
Table.4 Contribution of different characters towards genetic divergence among 20 genotypes of rice (Oryza sativa L.)

\begin{tabular}{|l|c|}
\hline \multicolumn{1}{|c|}{ Character } & Percent contribution towards divergence \\
\hline Days to 50\% Flowering & 13.68 \\
\hline Days to Maturity & 0.00 \\
\hline Plant Height (cm) & 13.16 \\
\hline Number of productive tillers/ Plant & 0.53 \\
\hline Panicle Length (cm) & 0.00 \\
\hline Number of total grains/ Panicle & 4.74 \\
\hline Hulling \% & 0.53 \\
\hline Milling \% & 0.00 \\
\hline Head Rice Recovery (\%) & 2.63 \\
\hline Volume Expansion Ratio & 0.00 \\
\hline Water Uptake & 42.11 \\
\hline L/B Ratio & 6.84 \\
\hline Kernel Elongation Ratio & 5.26 \\
\hline Amylose Content (\%) & 0.53 \\
\hline Grain Yield/ Plant (g) & 10.00 \\
\hline
\end{tabular}

Fig.1 Intra and Inter cluster distances of 20 rice (Oryza sativa L.) genotypes in five clusters based on Tocher method

Tocher Method

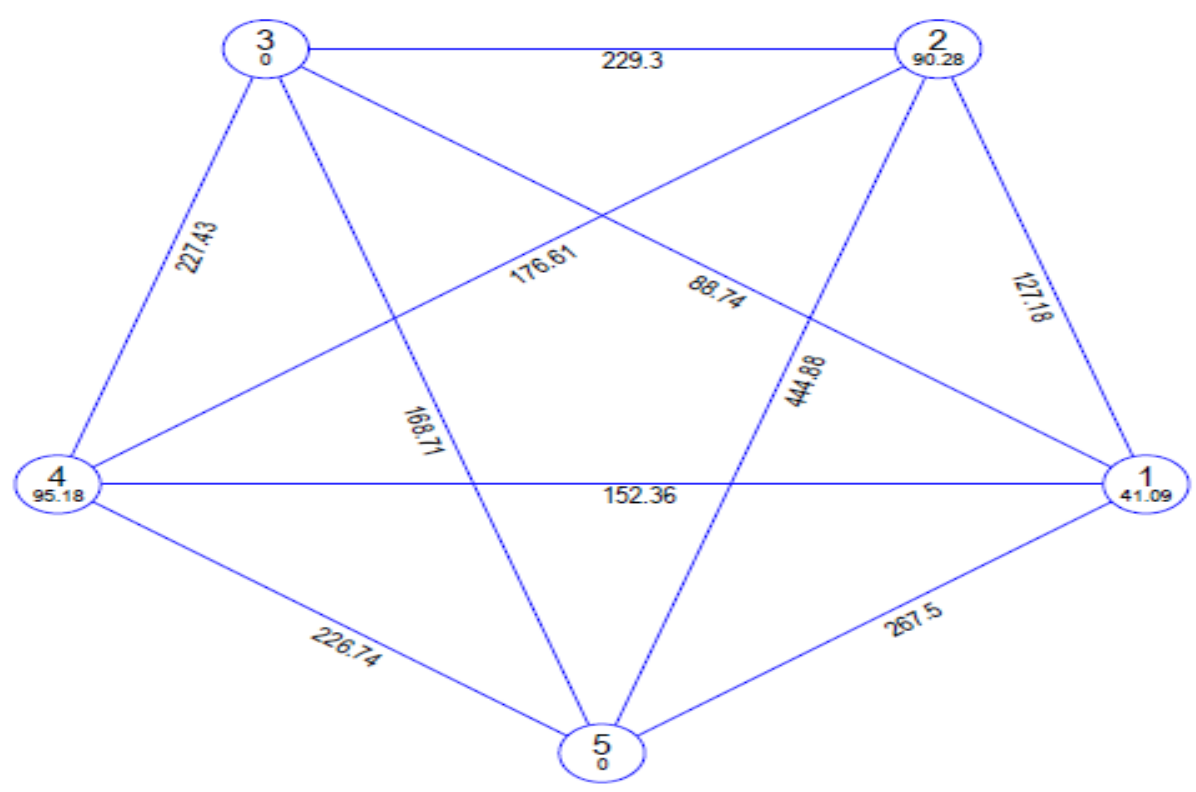

Mahalnobis Euclidean Disatnce (Not to the Scale) 
The cluster mean values for 15 characters are presented in Table 3. The data indicated a wide range of mean values between the characters. The cluster $\mathrm{I}$ is having highest mean value for panicle length and L/B ratio; cluster II for number of total grains per panicle, water uptake and grain yield per plant; cluster III for days to $50 \%$ flowering, days to maturity, hulling percentage, milling percentage, head rice recovery percentage, kernel elongation ratio and amylose content; cluster IV for plant height $(\mathrm{cm})$, number of productive tillers per plant and volume expansion ratio. Cluster mean values showed wide range among the genotypes studied, which indicates the presence of variation among the genotypes studied (Table 4).

Based on the perse performance and cluster mean values of characters, it can be concluded that, the hybrid S-8001 which is present in the cluster II is found to be superior over other hybrids and checks in the present study by having high mean values for the economically important characters viz., number of total grains per panicle, number of productive tillers per plant and yield per plant.

\section{References}

Allam, C.R., Jaiswal, H.K and Qamar, A. 2014. Divergence analysis for yield and quality traits in some indigenous basmati rice genotypes (Oryza sativa L.). International Journal of Applied Biology and Pharmaceutical Technology. 5(4): 257-263.

Allard, R.W. 1960. Principles of Plant Breeding. John Wiley and Sons Inc., New York. 485.

Ashok, S., Jyothula, D.P.B and Ratnababu, D. 2017. Genetic divergence studies for yield, yield components and grain quality parameters in rice (Oryza sativa L.). Electronic Journal of Plant Breeding. 8 (4): 1240-1246.
Beevi, H.A and Venkatesan, M. 2015. Genetic divergence studies in rice (Oryza sativa L.) genotypes under natural saline condition. Journal of the Andaman Science Association. 20 (1): 35-38.

Bhadra, S and Roy, B. 2014. Genetic diversity analysis of rice (Oryza sativa L.) genotypes under aluminium toxic hydroponic culture. Journal of Agriculture and Technology. 1 (2): 2632.

Bharathi, G., Veni, B.K., Ahamed, M.L and Lalitha, K.J. 2016. Studies on genetic divergence in high yielding rice (Oryza sativa L.) genotypes. Journal of Rice Research. 9 (2): 6-10.

Chakravorty, A and Ghosh, P.D. 2012. Genetic divergence in landraces of rice (Oryza sativa L.) of West Bengal India. Journal of Crop and Weed. 8 (2): 23-28.

Chandramohan, Y., Srinivas, B., Thippeswamy, S and Padmaja, D. 2016. Diversity and variability analysis for yield parameters in rice (Oryza sativa L.) genotypes. Indian Journal of Agricultural Research. 50 (6): 609-613.

Directorate of Economics and Statistics, GOI. Annual report 2016-17. Area and production of rice in India and Andhra Pradesh.

Directorate of Rice Research (DRR, Hyderabad). Vision 2050. 2013. www.drricar.org.

Dutta, A., Ghosh, P.D., Hossain, F and Sadhukhan, R. 2011. Genetic divergence of local germplasms of rice (Oryza sativa L.) in red and laterite tracts of West Bengal, India. Journal of Crop and Weed. 7 (1): 26-29.

Karuppaiyan, R., Chandan, K and Gopi, R. 2013. Variability, heritability and genetic divergence in lowland rice genotypes under the mid-hills of Sikkim. Oryza. 50 (1): 81-84.

Kumar, P., Sharma, V.K and Prasad, B.D. 
2015. Characterization of maintainer and restorer lines for wild abortive cytoplasmic male sterility in indica rice (Oryza sativa L.) using pollen fertility and microsatellite (SSR) markers. Australian Journal of Crop Science. 9 (5): 384-393.

Mahalanobis, P.C. 1936. On the generalized distance in statistics. Proccedings of National Institute of Science. (India), 12: 49-55.

Manohara, K.K and Singh, N.P. 2013. Genetic divergence among rice landraces of Goa. Oryza. 50 (2): 100104.
Sarawgi, A.K and Bisne, R. 2007. Studies on genetic divergence of aromatic rice germplasm for agro morphological and quality characters. Oryza. 44(1): 74-76.

Singh, P., Pandey, A., Mishra, S.B and Kumar, R. 2012. Genetic divergence study in aromatic rice. SABRAO Journal of Breeding and Genetics. 44 (2): 356369.

Vennila, S., Anbuselvam, Y and Palaniraja, K. 2011. Genetic divergence analysis using yield and quality traits in rice (Oryza sativa L.). International Journal of Recent Scientific Research. 2 (7): 237-239.

\section{How to cite this article:}

Devi, M., D.P.B. Jyothula, B. Krishnaveni and Rao, V.S. 2019. Genetic Divergence Studies in Rice (Oryza sativa L.) Hyrids for Yield, Yield Component Traits and Quality Parameters. Int.J.Curr.Microbiol.App.Sci. 8(06): 1577-1583. doi: https://doi.org/10.20546/ijcmas.2019.806.189 